\title{
Perbedaan Skor Developmental Quotient Menggunakan Cognitive Adaptive Test/Clinical Linguistic Auditory Milestone Scale pada Anak Stunting di Surakarta
}

Prima Evita Juwitasari, Harsono Salimo, Hari Wahyu Nugroho

Bagian Ilmu Kesehatan Anak Fakultas Kedokteran Universitas Sebelas Maret/RSUD Dr. Moewardi Surakarta

Latar belakang. Anak stunting berisiko mengalami gangguan perkembangan. CAT/CLAMS merupakan alat skrining gangguan perkembangan yang efektif dan akurat mendeteksi keterlambatan kognitif global dan bahasa.

Tujuan. Menganalisis perbedaan skor DQ anak stunting dan tidak stunting menggunakan CAT/CLAMS.

Metode. Penelitian deskriptif observasional dengan desain studi potong lintang yang dilakukan di beberapa puskesmas dan posyandu di Surakarta Agustus 2018-Mei 2019 terhadap anak usia 3-36 bulan dengan kriteria inklusi dan eksklusi. Hasil penelitian dikatakan bermakna jika nilai $\mathrm{p}<0,05$.

Hasil. Penelitian melibatkan 120 anak dengan rerata umur 19,7 $\pm 9,49$ bulan, terdiri dari 20\% anak stunting dan $80 \%$ tidak stunting. Skor CAT pada anak dengan stunting rata-rata 93,15 $\pm 5,24$ dan tidak stunting 94,37 $\pm 5,89, \mathrm{p}=0,203$ ( $\mathrm{p}>0,05$ ). Skor CLAMS pada anak stunting

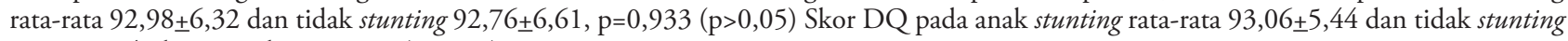
$93,57 \pm 5,84$, dengan nilai $\mathrm{p}=0,539(\mathrm{p}>0,05)$.

Kesimpulan. Tidak terdapat perbedaan yang signifikan pada skor DQ anak stunting dan tidak stunting menggunakan CAT/CLAMS. Sari Pediatri 2021;22(6):371-7

Kata kunci: stunting, developmental quotient (DQ), CAT/CLAMS

\section{The Difference of Developmental Quotient Score Using Cognitive Adaptive Test/Clinical Linguistic Auditory Milestone Scale for Stunting Child in Surakarta}

Prima Evita Juwitasari, Harsono Salimo, Hari Wahyu Nugroho

Background. Stunting is defined as body length or height divided by age less than -2 standard deviations according to the WHO growth curve. Developmental disorders are a problem that is often found in the community. CAT/CLAMS is an effective and accurate screening tool in detecting global cognitive and language delays.

Objective. analyze the differences in the DQ scores of stunting and non-stunting children using CAT / CLAMS.

Methods. This research is a descriptive observational cross sectional study. Children aged 3-36 months who visited several puskesmas and posyandu in Surakarta who met the inclusion criteria were included in the study. Height measurements were performed according to age and CAT / CLAMS examination. The dependent variable is Developmental Quotient (DQ), while the independent variable is stunting.

Result. A total of 120 children with a mean age of $19.7 \pm 9.49$ months participated in this study. There are $20 \%$ of children stunting and $80 \%$ of children not stunting. CAT scores in children with stunting children averaged $93.15 \pm 5.24$ and children without stunting on average $94.37 \pm 5.89$ with $\mathrm{p}=0.203$ ( $\mathrm{p}>0.05)$. CLAMS scores on stunting children were $92.98 \pm 6.32$ and non-stunting children were on average $92.76 \pm 6.61$. with a value of $\mathrm{p}=0.933$ ( $\mathrm{p}>0.05)$ DQ score in stunting children an average of $93.06 \pm 5.44$ and children who do not stunting an average of $93.57 \pm 5.84$ with a value of $\mathrm{p}=0.539(\mathrm{p}>0.05)$.

Conclusion. There were no significant differences in the DQ scores of stunting and non-stunting children with CAT/CLAMS. Sari Pediatri 2021;22(6):371-7

Keywords: stunting, developmental quotient (DQ), CAT/CLAMS

Alamat korespondensi: Prima Evita Juwitasari. Departemen Ilmu Kesehatan Anak Fakultas Kedokteran UNS Gedung Anggrek Lantai 4. Jl.Kolonel Sutarto No.132, Surakarta 57126. Email: primaevitajuwitasari@gmail.com 
S tunting merupakan masalah penting dibidang nutrisi anak, didefinisikan sebagai panjang badan atau tinggi badan berdasarkan usia kurang dari -2 standardeviasi. Stunting di seluruh dunia diperkirakan terjadi pada 162 juta balita. Angka stunting di Indonesia meraih peringkat ke-5 setelah India, Nigeria, Pakistan, dan China. Indonesia berada pada posisi lebih tinggi berdasarkan angka prevalensi dibandingkan Myanmar (35\%). Saat ini diperkirakan 8,9 juta anak di Indonesia mengalami stunting. Berdasarkan Riset Kesehatan Dasar (Riskesdas) angka kejadian stunting nasional adalah $36,7 \%$ pada tahun 2007. Pada tahun 2010, angka kejadian stunting turun menjadi 35,6\%, sedangkan pada tahun 2013, prevalensi stunting meningkat menjadi 37,2\%. Prevalensi stunting di propinsi Riau, DIY, DKI Jakarta, dan Kalimantan Timur paling rendah, yaitu $<30 \%$. Sementara di propinsi Nusa Tenggara Timur mencapai $>50 \%{ }^{1}$

Asupan nutrisi jangka panjang (malnutrisi kronis) menyebabkan stunting. Pemberian nutrisi yang tidak mencapai kebutuhan kalori dapat mengakibatkan terjadinya stunting. Dampak jangka pendek stunting antara lain angka morbiditas dan mortalitas meningkat, perkembangan intelegensi terganggu, motorik dan bahasa menjadi tidak optimal, serta beban biaya pelayanan anak sakit meningkat. Sementara dampak jangka panjang stunting antara lain tinggi badan tidak optimal saat dewasa, peningkatan risiko terjadinya obesitas pada usia dewasa, gangguan kesehatan reproduksi, kemampuan kognitif di sekolah tidak optimal, penurunan kapasitas belajar, potensi yang tidak tercapai, dan penurunan kapasitas serta produktivitas kerja. ${ }^{2-4}$

Gangguan perkembangan menjadi masalah yang sering ditemui klinisi di masyarakat. Diperkirakan delapan persen anak mengalami gangguan komunikasi dan gangguan kognitif. Komponen utama perkembangan kognitif meliputi perhatian, pengolahan informasi, dan memori. ${ }^{5}$

Penilaian perkembangan anak, salah satunya berdasarkan kemampuan kognitif yaitu perkembangan bahasa. Kemampuan berbahasa yang terlambat sangat memengaruhi kehidupan seorang anak. Deteksi gangguan perkembangan sejak dini melalui identifikasi dan intervensi sangat diperlukan dalam mencegah keterlambatan bahasa. Alat skrining yang mudah mendeteksi perkembangan bahasa adalah caput scales. ${ }^{5-7}$

Surveilans perkembangan (developmental survaillance) ketika anak sehat kontrol ke pelayanan kesehatan sangat direkomendasikan oleh American
Academy of Pediatrics (AAP). Anak usia 9, 18, dan 30 bulan serta pada anak dengan kecurigaan memiliki keterlambatan harus dilakukan skrining perkembangan ketika kontrol. Jika hasil skrining menunjukkan terjadi gangguan perkembangan, klinisi perlu melakukan evaluasi medis dan (developmental assessment) sehingga dapat segera dilakukan intervensi dini (early intervension) pada anak tersebut. ${ }^{7}$

Skrining perkembangan domain-specific untuk komunikasi/kognitif, antara lain, adalah capute scales (cognitif adaptive test/clinical linguistic auditory milestone scale-CAT/CLAMS), infant toddler checklist, early language milestone scale (ELMS-2), communication and symbolic behaviour scales-developmental profile (CSBSDP). ${ }^{5,6}$

Validitas capute scales sama seperti baku emas, yaitu bayles scales of infant development yang telah dibuktikan pada penelitian anak-anak dengan keterlambatan perkembangan (penelitian Hoon dkk tahun 1993, Wachtel dkk tahun 1994, dan Kube dkk tahun 2000), anak-anak dengan faktor risiko (penelitian Roosman dkk tahun 1994, Wachtel dkk tahun 1994, dan Vincer dkk tahun 2005), serta penelitian anak-anak dengan perkembangan atau penyakit khusus. ${ }^{5,6}$

Skor yang mendefinisikan proporsi perkembangan normal pada anak sesuai usia disebut developmental quotient (DQ). Penghitungan DQ secara aritmatika dengan cara membagi usia ekivalen anak dengan usia kronologis anak. Satuan DQ dinyatakan dalam satuan persen. ${ }^{5,6}$

Data penelitian tentang DQ pada anak dengan stunting masih belum banyak dilakukan. Oleh karena itu, penelitian ini diharapkan dapat menganalisis tentang perbedaan skor DQ anak stunting dan tidak stunting. Diharapkan hasil penelitian dapat menjadi masukan data dalam menyelesaikan masalah stunting di Indonesia.

\section{Metode}

Penelitian ini merupakan penelitian observasional dengan desain studi potong lintang. Penelitian ini dilakukan di beberapa Puskesmas dan Posyandu di kota Surakarta pada bulan Agustus 2018 - Mei 2019. Kriteria inklusi adalah anak usia 3-36 bulan yang berkunjung ke beberapa Puskesmas dan Posyandu dan orang tua/ wali bersedia mengikuti penelitian dan menandatangani 
lembar persetujuan. Kriteria eksklusi adalah anak dengan kondisi khusus seperti palsi serebral, hidrosefalus, sindorm Down, akondroplasia, gangguan pendengaran, dan gangguan penglihatan. Penelitian ini telah memperoleh kelaikan etik (ethical clearence) dari Dinas Kesehatan Kota Surakarta.

Orang tua/wali mengisi lembarpersetujuan terlebih dahulu, kemudian subyek dilakukan pemeriksaan tinggi badan, dan dimasukkan ke kurva pertumbuhan WHO. Subyek dan orang tua/wali menjalani pemeriksaan DQ menggunakan CAT/CLAMS edisi bahasa Indonesia. Semua data subyek penelitian dimasukkan ke lembar pengumpulan data pasien kemudian dilakukan analisis statistik.

Stunting didefinisikan sebagai tinggi badan yang suboptimal berdasarkan usia dengan panjang badan atau tinggi badan sesuai umur $<-2$ standar deviasi (heightfor-age-Z-score $/ \mathrm{HAZ}<-2 \mathrm{SD})$. Pengukuran panjang atau tinggi badan dilakukan oleh peneliti dibantu orang tua/ wali. Alat ukur menggunakan stadiometer. Pada anak di bawah umur 2 tahun atau panjang badan kurang dari $85 \mathrm{~cm}$, anak diposisikan berbaring sehingga kepala anak menyentuh papan penahan kepala dalam posisi bidang datar. Stunting dinyatakan dalam satuan persentil, yaitu jika panjang badan/umur atau tinggi badan/umur kurang dari $-2 \mathrm{SD}(\mathrm{PB} / \mathrm{U}<-2 \mathrm{SD}$ atau $\mathrm{TB} / \mathrm{U}<-2 \mathrm{SD})$. Skala pengukuran variabel stunting adalah kategorik, yaitu stunting dan tidak stunting.

Developmental quotient merupakan skor yang menyatakan proporsi perkembangan normal sesuai usia. Hasil DQ didapatkan dengan cara membagi usia ekivalen anak dengan usia kronologis anak, dan dinyatakan dalam prosentase perkembangan yang diharapkan untuk usia tersebut ${ }^{5}$.

CAT/CLAMS edisi bahasa Indonesia digunakan sebagai alat ukur. Pengukuran dan pengisian dara dilakukan oleh peneliti.

Setiap pengukuran dilakukan dalam waktu 15-20 menit. Satuan DQ dinyatakan dalam prosentase.

Skala pengukuran kategorikal, yaitu DQ normal $(\mathrm{DQ} \geq 85)$ dan tidak normal $(\mathrm{DQ}<85)$. Alat ukur CAT/ CLAMS merupakan alat diagnostik dalam mendeteksi keterlambatan kognitif global dan keterlambatan bahasa. ${ }^{5}$ Hasil pengukuran CAT/CLAMS dinyatakan sebagai DQ, dinyatakan dalam prosentase dengan skala kategorikal, yaitu DQ normal (DQ $\geq 85)$ dan tidak normal $(\mathrm{DQ}<85)$.

Data yang diambil tersebut dimasukkan ke dalam program perangkat lunak SPSS ${ }^{\bullet} 24$. Karakteristik subyek penelitian meliputi data jenis kelamin, usia, stunting atau tidak stunting disajikan dalam bentuk tabel. Perbedaan skor DQ menggunakan CAT/CLAMS isajikan dalam bentuk tabel dan dianalisis menggunakan uji Mann Whitney. Hasil penelitian dikatakan bermakna jika didapatkan nilai $\mathrm{p} \leq 0,05$.

\section{Hasil}

Tabel 1 Karakteristik subyek penelitian

\begin{tabular}{lc}
\hline Karakteristik & Hasil \\
\hline Usia (bulan) & $19,70 \pm 9,49$ \\
Jenis_kelamin (\%) & \\
$\quad$ Laki-laki & $62(51,7)$ \\
$\quad$ Perempuan & $58(48,3)$ \\
Stunting (\%) & \\
$\quad$ Ya & $24(20,0)$ \\
$\quad$ Tidak & $96(80,0)$ \\
\hline (Hasil pengolahan data tahun 2020) &
\end{tabular}

Berdasarkan Tabel 1 diketahui bahwa usia subyek

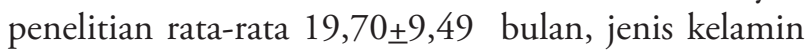
sebagian besar laki-laki, yaitu $62(51,7 \%)$ anak, dan perempuan $58(48,3 \%)$ anak. Kejadian stunting didapatkan 24 20,0\%) anak, sedangkan sisanya 96 $(80,0 \%)$ tidak stunting.

Hasil gambaran usia dan jenis kelamin berdasarkan kejadian stunting dapat dilihat pada Tabel2 sebagai berikut.

Tabel 2 Gambaran usia dan jenis kelamin berdasarkan kejadian stunting

\begin{tabular}{lccc}
\hline Karakter & $\begin{array}{c}\text { Stunting } \\
(\mathrm{n}=24)\end{array}$ & $\begin{array}{c}\text { Tidak stunting } \\
(\mathrm{n}=96)\end{array}$ & $\mathrm{p}$ \\
\hline Usia (bulan) & $20,79 \pm 9,54$ & $19,42 \pm 9,51$ & 0,513 \\
Jenis kelamin (\%) & & & 0,120 \\
$\quad$ Laki-laki & $9(37,5)$ & $53(55,2)$ & \\
$\quad$ Perempuan & $15(62,5)$ & $43(44,8)$ & \\
\hline
\end{tabular}

(Hasil Pengolahan data tahun 2020)

Berdasarkan Tabel 1 diketahui bahwa usia anak dengan kejadian stunting rata-rata $20,79 \pm 9,54$ bulan dan tidak stunting rata-rata $19,42 \pm 9,51$ bulan Dengan nilai $p=0,513(p>0,05)$. Hal ini berarti bahwa tidak terdapat perbedaan yang signifikan karakteristik subyek penelitian berdasarkan usia antara anak stunting dan 
tidak stunting.

Jenis kelamin dengan kejadian stunting sebagian besar perempuan, $15(62,5 \%)$ dan tidak stunting sebagian besar laki-laki,53 (55,2\%) anak dengan nilai $p=0,120(p>0,05)$. Hal ini berarti bahwa tidak terdapat perbedaan yang signifikan karakteristik subyek penelitian berdasarkan jenis kelamin antara anak stunting dan anak tidak stunting.

Tabel 3. Perbedaan skor DQ menggunakan CAT/CLAMS stunting dibanding tidak stunting

\begin{tabular}{lccc}
\hline Variabel & $\begin{array}{c}\text { Stunting } \\
(\mathrm{n}=24)\end{array}$ & $\begin{array}{c}\text { Tidak stunting } \\
(\mathrm{n}=96)\end{array}$ & $\mathrm{p}$ \\
\hline CAT & $93,15 \pm 5,24$ & $94,37 \pm 5,89$ & 0,203 \\
CLAM & $92,98 \pm 6,32$ & $92,76 \pm 6,61$ & 0,933 \\
DQ & $93,06 \pm 5,44$ & $93,57 \pm 5,84$ & 0,536 \\
\hline
\end{tabular}

(Hasil Pengolahan data tahun 2020)

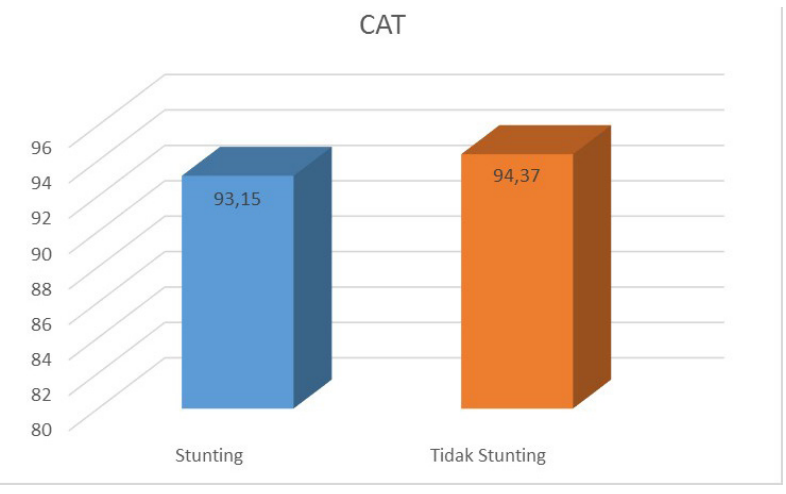

Gambar 1. Diagram batang gambaran skor CAT anak stunting dan tidak stunting

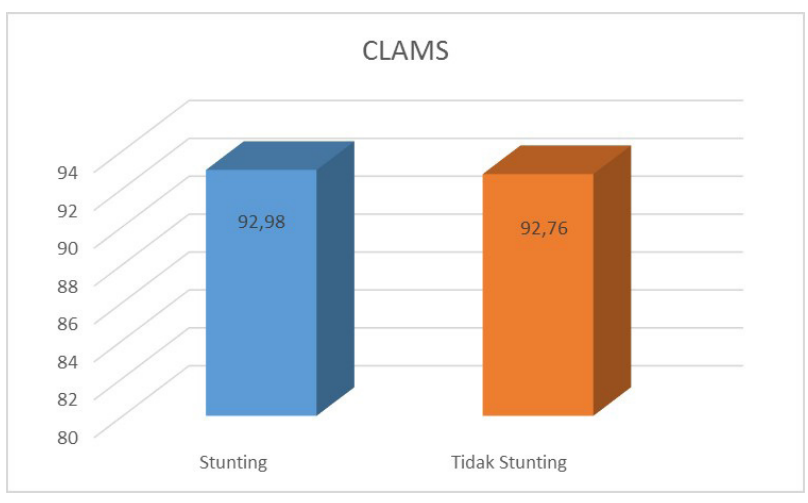

Gambar 2. Diagram batang gambaran skor CLAMS antara anak stunting dan tidak stunting

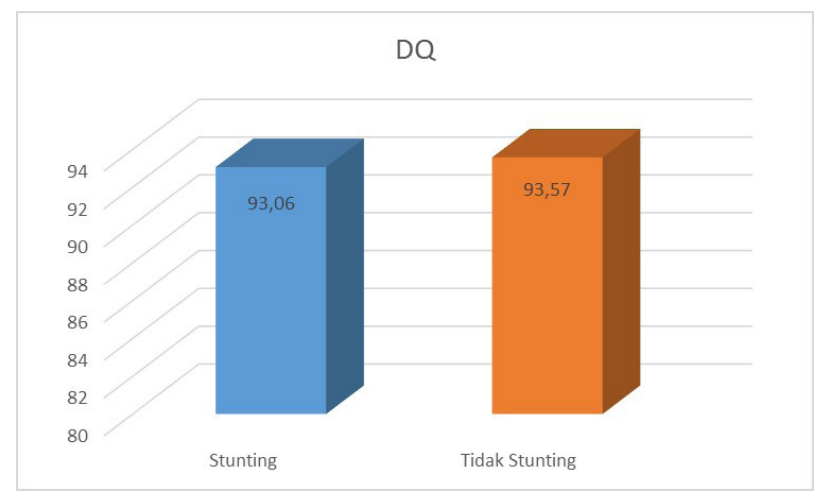

Gambar 3. Diagram batang gambaran skor DQ anak stunting dan tidak stunting

Perbedaan skor DQ menggunakan CAT/CLAMS pada anak stunting dibanding tidak stunting dilakukan dengan uji Mann Whitney karena berupa numerik dengan hasil uji normalitas Shapiro wilk tidak berdistribusi normal (lampiran). Perbedaan skor DQ menggunakan CAT/CLAMS pada anak stunting dibanding tidak stunting tertera pada Tabel 3 .

Pada tabel 3 diketahui bahwa skor CAT pada anak dengan kejadian stunting rata-rata 93,15 $\pm 5,24$ dan tidak stunting rata-rata 94,37 $\pm 5,89$. Nilai $\mathrm{p}=0,203$ ( $>0,05)$ yang berarti bahwa tidak terdapat perbedaan yang signifikan Skor CAT antara anak stunting dan tidak stunting.

Skor CLAMS pada anak dengan kejadian stunting rata-rata $92,98 \pm 6,32$ dan anak dengan kejadian tidak stunting (normal) rata-rata 92,76 $\pm 6,61$. Nilai $p=0,933$ ( $p>0,05$ ) yang berarti bahwa tidak terdapat perbedaan yang signifikan skor CLAMS antara anak stunting dan anak tidak stunting.

Skor DQ pada anak stunting rata-rata 93,06 $\pm 5,44$ dan anak tidak stunting rata-rata 93,57 $\pm 5,84$. Nilai $\mathrm{p}=0,539(\mathrm{p}>0,05)$ yang berarti bahwa tidak terdapat perbedaan yang signifikan Skor DQ antara anak stunting dan tidak stunting.

\section{Pembahasan}

Stunting masih menjadi masalah kesehatan utama. Indonesia menduduki peringkat kelima sebagai negara dengan jumlah balita tertinggi mengalami stunting. Peningkatan morbiditas dan mortalitas, penurunan perkembangan kognitif motorik dan bahasa, serta 
beban pelayanan anak sakit yang meingkat merupakan dampak jangka pendek dari stunting. Sementara dampak jangka panjang stunting meliputi tinggi badan yang tidak optimal saat dewasa, risiko obesitas yang tinggi saat dewasa, gangguan kesehatan reproduksi, kemampuan kognitif di sekolah yang menurun, kapasitas dan produktivitas kerja pun menurun saat dewasa. Oleh karena itu, peran dokter dan tenaga kesehatan sangat dibutuhkan dalam menurunkan angka stunting di Indonesia.

Gangguan perkembangan dan perilaku diperkirakan terjadi pada $12 \%-16 \%$ anak di Amerika Serikat. ${ }^{31}$ Gangguan perkembangan meliputi gangguan komunikasi dan kognitif. Gangguan perkembangan berpotensi menjadi masalah di sekolah hingga periode kehidupan selanjutnya pada anak. Skrining dan deteksi dini sangat diperlukan dalam memantau perkembangan anak. Jika gangguan perkembangan dapat dideteksi sejak dini, diagnosis dan tatalaksana dapat dilakukan sejak awal. Oleh karena itu, deteksi gangguan perkembangan dengan skrining rutin ketika kontrol di pelayanan kesehatan sangat besar dampaknya. ${ }^{32,33}$

Menurut Soedjatmiko, ${ }^{33}$ langkah-langkah deteksi gangguan tumbuh kembang meliputi anamnesis, pemeriksaan fisik, skrining perkembangan, dan pemeriksaan lanjutan. Perkembangan meliputi bertambahnya kemampuan gerak kasar dan halus,pendengaran, penglihatan, komunikasi, bicara, sosio-emosional, kognitif, hingga perkembangan moral. Kebutuhan dasar tumbuh kembang meliputi aspek asuh (nutrisi, imunisasi, tempat tinggal), asih/psikososial, dan asah (komunikasi, kasih sayang). Faktor risiko perkembangan perlu dianalisis. Faktor ibu sebagai lingkungan mikro, faktor keluarga dan kondisi tempat tinggal sebagai lingkungan mini, faktor tetangga, polusi udara, budaya, akses kesehatan, dan pendidikan merupakan lingkungan meso, dan kebijakan pemerintah sebagai lingkungan makro memiliki peran penting dalam perkembangan seorang anak. ${ }^{33}$

Alat skrining gangguan perkembangan semakin beragam. Pemilihan alat skrining yang tepat dan mudah dilakukan dalam praktik sehari-hari sangat penting. ${ }^{33}$ Terdapat beberapa alat skrining perkembangan yang dapat dipilih. Kuesioner Pra Skrining Perkembangan (KPSP) berisi sepuluh pertanyaan yang ditujukan kepada orang tua. Pediatric Symptom Checklist (PSC) berisi 35 pertanyaan mengenai perilaku anak yang ditanyakan kepada orang tua. Denver II dapat dikerjakan pada bayi baru lahir hingga usia 6 tahun dapat mendeteksi aspek perkembangan yang penting, yaitu gerak kasar, gerak halus, bahasa, dan personal sosial. CHAT (Checklist for Autism in Toddler) merupakan alat skrining gangguan autis pada anak. ${ }^{35}$

Skrining perkembangan dilakukan pada semua anak usia 9 bulan, 18 bulan, dan 30 bulan. ${ }^{9}$ Penelitian menggunakan CAT/CLAMS ini dapat dipertimbangkan dikerjakan pada skrining perkembangan anak jika terdapat indikasi yang sesuai. Gangguan kognitif dan bahasa dapat dinilai menggunakan CAT/CLAMS. ${ }^{32-34}$ Pada penelitian kami, alat skrining perkembangan yang digunakan adalah Cognitive Adaptive Test/ Clinical Lingistic and Auditory Milestone Scale (CAT/CLAMS). CAT/CLAMS dapat digunakan sehari-hari karena praktis dan reliabel dalam mendeteksi gangguan perkembangan. ${ }^{7}$

Hairunis $\mathrm{dkk}^{34}$ menganalisis hubungan kondisi nutrisi dan stimulasi terhadap perkembangan balita. Penelitian tersebut berlangsung pada Februari-April 2018, secara analitik observasional dengan potong lintang, melibatkan 114 balita di propinsi Nusa Tenggara Barat (NTB). Status gizi berdasarkan tinggi badan sesuai umur sebesar 40,5\% berperawakan pendek. Hasil penelitian tersebut menunjukkan hubungan antara stimulasi dan perkembangan balita yang bermakna. Kesimpulan lain didapatkan bahwa balita berperawakan normal memiliki kemungkinan 3,3 kali mengalami perkembangan yang optimal dibanding balita dengan perawakan pendek maupun stunting. Balita yang diberi stimulasi berpeluang 3,1 kali lebih baik perkembangannya dibanding balita yang jarang diberi stimulasi. Penelitian Hairunis tersebut menunjukkan bahwa status gizi dan stimulasi tumbuh kembang berperan penting dalam tumbuh kembang anak. Stimulasi dan malnutrisi yang kurang menjadi faktor yang penting dalam gangguan perkembangan. Interaksi ibu dan anak serta stimulasi dini sangat berperan dalam perkembangan seorang anak. $^{32}$

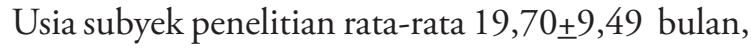
mayoritas adalah anak laki-laki $(51,7 \%)$. Kejadian stunting didapatkan pada $24(20,0 \%)$ anak. Stunting lebih sering ditemukan pada anak laki-laki dibanding perempuan. Dibandingkan penelitian Hairunis $\mathrm{dkk}^{34}$ kejadian stunting di kota Surakarta lebih rendah. Peneliti melakukan skrining perkembangan menggunakan CAT/CLAMS guna mendapatkan data apakah didapatkan gangguan perkembangan atau tidak. Hasil penelitian ini tidak sesuai dengan penelitian Hairunis. Semua anak stunting memiliki skor DQ normal, dan 
anak tidak stunting sebagian besar memiliki skor DQ normal pada penelitian ini.

Penelitian tentang skrining perkembangan menggunakan berbagai macam alat skrining, di antaranya adalah CAT/CLAMS. Windiani ${ }^{35}$ melakukan penelitian di tempat penitipan anak Werdhi Kumara I di kota Denpasar menggunakan CAT/CLAMS melibatkan 49 anak. Penelitian pada September 2009 tersebut menggunakan desain deskriptif potong lintang dengan populasi anak usia kurang dari atau sama dengan 36 bulan. Hasil skrining perkembangan normal didapatkan pada empat puluh satu anak (83\%), tujuh anak dengan hasil suspek, dan satu anak didapatkan retardasi mental. Penelitian yang dipublikasikan pada tahun 2010 tersebut menyimpulkan bahwa prevalensi gangguan kognitif dan bahasa pada anak sebesar 14\% berdasarkan pemeriksaan CAT/CLAMS. Jenis kelamin laki-laki maupun perempuan memiliki peluang sama terhadap terjadinya gangguan perkembangan. Latar belakang tingkat pendidikan yang baik pada ayah dan ibu dan kedua orang tua yang bekerja memiliki peluang lebih besar terhadap terjadinya gangguan perkembangan pada anak. Hal ini dimungkinkan karena kesibukan orang tua menyebabkan perhatian pada keluarga menjadi berkurang sehingga anak kurang mendapatkan stimulasi. ${ }^{35}$

Jumlah subyek sebesar seratus dua puluh anak berusia 3-36 bulan didapatkan usia rata-rata 19,7 $\pm 9,49$ bulan. Skor DQ pada anak stunting dan tidak stunting didapatkan tidak ada perbedaan yang bermakna. Penelitian lainnya mengenai gangguan perkembangan anak usia 1-3 tahun secara random sampling oleh Susanti ${ }^{36}$ di Surabaya menunjukkan, nilai CAT ratarata sebesar 92,58 $\pm 16,10$ dan nilai CLAMS rata-rata $102,67 \pm 13,63$ dnegan FSDQ rata-rata 97,88 $\pm 12,26$. Penelitian menggunakan desain deskriptif potong lintang di Kecamatan Bulak tersebut mengambil subyek 98 anak dengan kesimpulan 84\% anak memiliki skor DQ normal, 13\% anak dinyatakan suspek, dan 2\% anak mengalami developmental delay. Prevalensi gangguan perkembangan di Kecamatan Bulak sebesar 15,8\%. ${ }^{36}$

Penelitian tersebut memiliki kesamaan dengan penelitian ini yang menggunakan desain deskriptif dan studi potong lintang. Namun, hasil penelitian sebelumnya berbeda dengan penelitian ini, semua anak memiliki hasil DQ baik. Skor DQ rata-rata pada anak stunting 93,06 5,44 dan anak tidak stunting rata-rata $93,57 \pm 5,84$. Tidak terdapat perbedaan bermakna skor
DQ antara anak stunting dan anak tidak stunting. Semua anak stunting memiliki skor DQ normal, dan anak tidak stunting sebagian besar memiliki skor DQ normal.

Keterbatasan pada penelitian ini adalah tidak mempertimbangkan kondisi anak sebelum dilakukan pemeriksaan CAT/CLAMS. Peneliti menyesuaikan waktu penelitian dengan jadwal Posyandu yang berlangsung 1 kali dalam 1 bulan sehingga membutuhkan waktu lebih panjang dalam proses pengambilan data. Faktor pendukung, seperti faktor ibu, keluarga, lingkungan, dan sosial ekonomi tidak dipertimbangkan dalam analisis penelitian. Kebaruan penelitian ini, yaitu dilakukan pada 120 anak yang berkunjung ke Posyandu dan Puskesmas di wilayah kota Surakarta. Selain itu, penelitian dilakukan dengan menganalisis DQ antara anak stunting dan anak tidak stunting. Hal ini tidak dilakukan pada penelitian sebelumnya yang menganalisis DQ saja maupun menganalisis tentang stunting saja.

\section{Kesimpulan}

Tidak terdapat perbedaan bermakna antara skor DQ anak stunting dan anak tidak stunting.

\section{Daftar pustaka}

1. Kementrian Kesehatan RI. Laporan riset kesehatan dasar. Badan penelitian dan pengembangan kesehatan kementrian kesehatan RI. Jakarta: Kemkes RI; 2013.

2. Prendergast AJ, Humprey JH. The stunting syndrome in developing countries. Pediatr Int Child Health 2014;34:25065.

3. Black MM, Walker SP, Fernald LC, dkk. Advancing early childhood development: from science to scale 1, early childhood development coming of age: science through the life course. Lancet 2017;389:77-90.

4. Casale D, Desmond C. Recovery from stunting and cognitive outcomes in young children:evidence from south African Birth to twenty cohort study. J Dev Orig Health Dis 2016;7:163-71.

5. Accardo PJ, Capute AJ. The capute scale: cognitive adaptive test/ clinical linguistic \& auditory milestone scae (CAT/ CLAMS). Baltimore: Paul H Brookes Publishing Co; 2005.h.1-45.

6. Leppert ML, Shank TP, Shapiro BK, Capute AJ. The Capute Scales: CAT/CLAMS-a pediatric assessment tool for the early detection of mental retardation and communicative disorders on Mental retardation and developmental disabilities research reviews. Wiley-Liss Inc; 1998.h.14-19. 
7. Dhamayanti M, Herlina M. Skrining gangguan kognitif dan bahasa dengan menggunakan Capute Scales (Cognitive Adaptive Test/Clinical Linguistic \& Auditory Milestone ScaleCAT/CLAMS). Sari Pediatri 2009;11:189-98.

8. Kar BR, Rao SL, Chandramouli BA. Cognitive development in children with chronic protein energy malnutrition. BMC Behaviour and brain function 2008;4:31.

9. Santos IS, Matijasevich A, Domingues MR, Barros AJD, Victora CG, Barros FC. Late preterm birth is a risk factor for growth faltering in early childhood: a cohort study. BMC Pediatrics 2009;9:71.

10. Selina L, Pamela D, Richard H. Lancet early childhood development series steering committee. A good start will ensure sustainable future for all. Lancet 2017;389:8-9.

11. Victora CG, Adair L, Fall C, dkk. Maternal and child undernutrition: consequences for adult health and human capital. Lancet 2008;371:340-57.

12. Wasaraka YNK, Prawirohartono EP, Soenarto Y. Perbedaan proporsi stunting pada anak usia 12-24 bulan berdasarkan pemanfaatan pelayanan posyandu di Kabupaten Jayapura, Papua. Jurnal gizi klinik Indonesia 2015;12:72-8.

13. American academy of Pediatrics. Council on children with disabilities. Identifying infants and young children with developmental disorders in the medical home:an algorithm for developmental surveillance and screening. Pediatrics 2006;118:405-19.

14. WHO. Nutrition landscape information system (NLIS) country profile indicators: interpretation guide. Geneva: WHO; 2011.

15. Departemen Kesehatan RI. Pedoman pelaksanaan stimulasi. deteksi dan intervensi dini tumbuh kembang anak di tingkat pelayanan kesehatan dasar. Jakarta : Depkes RI; 2009.

16. McGregor SG, Cheung YB, Cueto S, dkk. Child development in developing countries 1, developmental potential in the first 5 years for children in developing countries. Lancet 2007; 369:60-70.

17. Hudaini, Ahmad A, Gustiana. Hubungan stunting dan stimulasi dengan perkembangan motorik kasar pada anak taman kanak-kanan usia 3-5 tahun di Banda Aceh. J Politek Kesehat 2011;3-6.

18. Manji S, Arnold C, Gowani S. How are we doing and how do we get in right for children? Evolution of the roles of the public and private sector in early childhood care and education in efforts to achieve EFA goal1. Unites Nations Educational, Scientific and Cultural Organization 2015;88:24-34.

19. Casale D, Desmond C. Recovery from stunting and cognitive outcomes in young children: evidence from The South African Birth to Twenty Cohort Study. J Dev Orig Health Dis 2016;7:163-71.

20. Hoddinott J, Maluccio JA, Behrman JR, Flores R, Martorell R. Effect of nutrition intervention during early childhood on economic productivity in Guatemalan adults. Lancet 2008;317:411-6.
21. Lu C, Black MM, Richter LM. Risk of poor development in young children in low-income and middle-income countries: an estimation and analysis at the global, regional, and country level. Lancet Global Health, 2016. 4, e916-22.

22. Hackman DA, Gallop R, Evans GW, Farah MJ. Socioeconomic status and executive function: developmental trajectories and mediation. Dev Sci: 2015;18:686-702.

23. Glascoe FP, Marks KP, Bauer NS. Developmental behavioral screening and surveillance. Dalam: Kliegman, Stanton S, Geme St, Schor, penyunting. Nelson textbook of pediatrics Edisi ke20 volume 1. Philadelphia: Elsevier Saunders; 2016.h.90-101.

24. Sameroff A, penyunting. The transactional model of development: how children and context shape each other. Washington DC: American Psychological Association 2009.h.78-89.

25. Noble KG, Houston SM, Brito NH, dkk. Family income, parental education and brain structure in children and adolescents. Nat Neurosci 2015;18:773-8.

26. Pavlakis AE, Noble K, Pavlakis SG, Ali N, Frank Y. Brain imaging and electrophysiology biomarkers: is there a role in poverty and education outcome research?. Pediatr Neurol 2015;52:383-8

27. Pantaleon MG, Hadi H, Gamayanti IL.. Stunting berhubungan dengan perkembangan motorik anak di kecamatan Sedayu, Bantul, Yogyakarta. Jurnal Gizi dan Dietetik Indonesia 2015;3:10-21

28. Cheung Y, Yip P, Karlberg J. Fetal growth, early postnatal growth and motor development in Pakistan infants. Int J Epidemiol 2001;30:66-74.

29. Dahlan. Langkah-langkah membuat proposal penelitian bidang kedokteran dan kesehatan seri 2. Edisi ke-3. Jakarta: Sagung Seto; 2012.h.79-97.

30. Hendarto A, Sjarif D. Antropometri anak dan remaja. Dalam: Buku ajar Nutrisi pediatrik dan penyakit metabolik. Jilid I cetakan kedua revisi. IDAI; 2014.h. 27.

31. American Academy of Pediatrics. Committee on children with disabilities. Developmentan surveillance and screeing of infants and young children. Pediatrics 2001;108:192-6.

32. Soetjiningsih. Skrining dan pemantauan perkembangan anak. Dalam: Soetjiningsih, Ranuh IGN. Tumbuh kembang anak. Edisi 2. Jakarta: EGC; 2012.h.168-77.

33. Soedjatmiko. Deteksi dini gangguan tumbuh kembang balita. Sari Pediatri 2001;3:175-88.

34. Hairunis MH, Salimo H, Dewi YLR. Hubungan status gizi dan stimulasi tumuh kembang dengan perkembangan balita. Sari Pediatri 2018;20:146-51.

35. Windiani IGA, Soetjiningsih. Penilaian CAT (Cognitive Adaptive Test)/ CLAMS (Clinical Linguistic \& Auditory Milestone Scale) pada anak di tempat penitipan anak Werdhi Kumara I Denpasar. Sari Pediatri 2010;12:228-32.

36. Susanti Dwi. Language and visuomotor development in children aged 1-3 years in subdistrick Bulak, Surabaya. Folia Medica Indonesiana 2016;52:94-7. 